Article

\title{
Farmers' Adaptation Strategies to Climate Change and Their Implications in the Zou Department of South Benin
}

\author{
Adégnandjou Mahouna Roland Fadina and Dominique Barjolle * \\ Department of Environmental Systems Science, ETH Zurich, 8092 Zurich, Switzerland; rolandfadina@gmail.com \\ * Correspondence: barjolle@ethz.ch; Tel.: +41-765-784-404
}

Received: 30 November 2017; Accepted: 18 January 2018; Published: 21 January 2018

\begin{abstract}
Climate change is a global phenomenon. Its impact on agricultural activities in developing countries has increased dramatically. Understanding how farmers perceive climate change and how they adapt to it is very important to the implementation of adequate policies for agricultural and food security. This paper aims to contribute to an understanding of farmers' adaptation choices, determinants of the adaptation choices and the long-term implications of the adaptation choices. Data were collected from 120 respondents in the Zou Department of Benin. A binary logit model was used to analyze the factors influencing household decisions to adapt to climate change. Multinomial logistic regression analysis was estimated to analyze the factors influencing households' choice of adaptation strategies to climate change. The results show that farmers have a developed perception of climate change. These changes are translated by rainfall disturbances (rainfall delays, early cessation, bad rainfall distribution etc.), shortening of the small dry season, increasing of temperature and sometimes, violent winds. The survey reveals that Benin farmers adopt many strategies in response to climate change. These strategies include "Crop-livestock diversification and other good practices (mulching, organic fertilizer)," "Use of improved varieties, chemical fertilizers and pesticides," "Agroforestry and perennial plantation" and "Diversification of income-generating activities." The findings also reveal that most of the respondents use these strategies in combination. From the binary logit model, we know that "farming experience" and "educational level of household head" positively influence adaptation decisions. The result of the multinomial logit analysis shows that farming experience, educational level, farm size and gender have a significant impact on climate change adaptation strategies. Based on in-depth analysis of each strategy, we identify crop diversification and agroforestry as being the most promising strategies with benefits for farmers, the environment and future generations.
\end{abstract}

Keywords: climate change; adaptation strategy; agriculture; agricultural policy

\section{Introduction}

In sub-Saharan Africa, 63\% of the population continues to depend on agriculture [1]. Climate variability and change are major challenges hampering agricultural productivity in this region. Indeed, Africa is one of the most vulnerable continents to the current climate variability with strong economic impacts [2]. This vulnerability is accentuated by development challenges such as endemic poverty, ecosystem degradation and limited access to capital, markets, infrastructure and technology [3].

In Benin, where agriculture is the second largest component of the economy with a contribution of $38 \%$ to gross domestic product (GDP) and about 70-80\% of export earnings [4], the negative impacts of climate change on this sector are obvious. Indeed, Benin has been experiencing strong weather variability characterized by a fluctuation of the period and duration of precipitation, a change in annual rainfall, an increasingly hot climate, drought, soil degradation, unexpected flooding, high 
winds and the proliferation of diseases and pests [5-9]. Thus, the importance of adaptation measures for the $61.1 \%$ of the population of the country living in rural areas [10] and dependent on agriculture for their subsistence becomes an absolute priority. In order to reduce the potential negative, direct or indirect effects of climate change on the agri-food system, populations must adapt and economic systems must be adapted to future climatic contexts [11]. Adaptation to climate change is a process that initially requires famers to perceive that the climate has changed and then identify the necessary adaptations to be implemented [12].

In Africa, some work has been carried out in a global way on farmers' perceptions of climate change and adaptation strategies, in particular those of Simelton et al. [13] in Malawi and Botswana, those of Comoé [14] in the Ivory Coast, those of Assoumana et al. [15] in Niger and those of Gebreeyesus [16] in Kenya. These studies revealed that all respondents have observed a number of changes in the overall climate pattern. The main perceptions are related to the duration of the rainy season, the variability of onset and rainfall amount. In Benin, some studies have also been conducted on farmers' perceptions of climate change. These include the work of Houssou-Goe [17] in the Couffo department, Gnanglè et al. [18] in the Center of Benin, Gnanglè [5] and Loko et al. [6] in the north of Benin. This previous research has demonstrated that adaptation strategies to climate change are context and locality dependent. Farmers' perceptions and adaptation strategies to climate change in the Zou Department have hardly been studied. However, this region is an area with a high agricultural potential, with $60.7 \%$ of its population living in rural areas and $47 \%$ being farmers [19]. This raises the following research questions: How do the actors in the agricultural sector, the smallholder farmers in this region, perceive these climate changes and how do they react? Do their adaptation strategies take into account future generations?

\section{Materials and Methods}

\subsection{Presentation of Study Area}

The study was conducted in the Zou Department of southern Benin (Figure 1). It is a plateau area from $200 \mathrm{~m}$ to $300 \mathrm{~m}$ altitude. There is a transitional climate between the sub-equatorial climate and the humid tropical climate of the Sudan-Guinean type of North Benin. The average annual rainfall varies between $900 \mathrm{~mm}$ and $1200 \mathrm{~mm}$. The period of vegetative growth varies between 80 and 100 days. In Zou, there are two rainy seasons (March to July) and (August to October). The agricultural calendar follows the rainfall pattern [19]. The soils are clay-sandy ferralitic land, which is highly degraded but very well drained with a low retention capacity. Deep and easy to work, they are suitable for almost any crop. Vertisols and hydromorphic soils are also found in depressions. The vegetation is dominated by a natural palm plantation (Elaeis guineensis) and grasses but a few classified or sacred forests are also encountered [19]. The department of Zou is subdivided into nine communes namely: Abomey, Agbangnizoun, Bohicon, Covè, Djidja, Ouinhi, Zangnanado, Za-kpota and Zogbodomey.

The population is mainly rural and agriculture is the main activity, occupying $47 \%$ of the population [19]. 


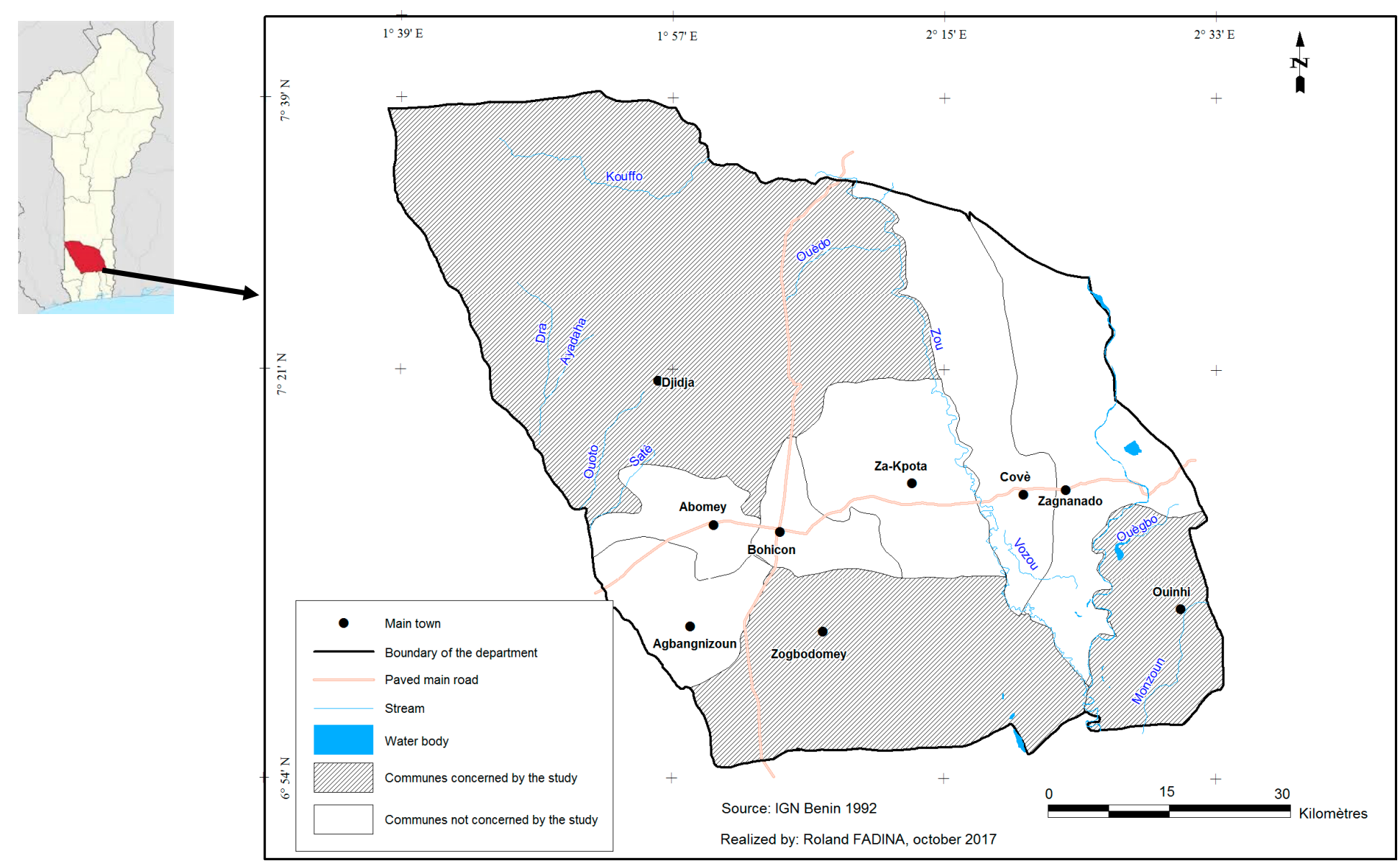

Figure 1. Map of the Zou Department, the study area. 


\subsection{Methodology}

In this study, both quantitative and qualitative data were collected through household surveys. For data collection, three communes were selected based on their agricultural production (total yields of crop production and percentage of agricultural labor force). This specific criterion was used because of the purpose of the study, which is to study farmers' adaptation strategies to climate change. These were the communes of Djidja, Ouinhi and Zogbodomey. The population of interest was made up of the set of agricultural households in these three communes. The sampling unit was the agricultural household. In each commune, two villages were selected based on their agricultural production. The respondents were selected randomly according to their availability and to a balanced coverage of the socioeconomic diversity of the farms in the study villages. In each village, 20 farmers (head of household) were surveyed. In all study areas, a total of 120 respondents were interviewed. Additionally, six focus groups were conducted. Each focus group was attended by 8 to 12 farmers, made up of men and women. The data collected relates to socioeconomic characteristics, farmers' perceptions of climate change and adaptation strategies developed by farmers to address climate change. The individual interview contained 32 questions in total including check-all and forced-choice questions followed by a comprehensive discussion with the farmers. The questions focused on five themes: (1) socioeconomic characteristics; (2) climate and climate change information; (3) farmers' perception of climate change in general; (4) farmers' perception of rainfall patterns; (5) farmers' perception of temperature patterns; (6) farmers' perception of climate change effects. The questions related to the general climate change perception were open ended, while the specific questions related to climate change effect and temperature and rainfall were organized with sequential options. Answers were coded into different actual values. The objectives of the individual survey were to collect the information needed for in-depth analysis of the research questions, whereas the ones of the focus group were to verify the information obtained during the individual surveys. The same approach was used by Simelton [13] and Gebreeyesus [16].

The Statistical Package for Social Sciences (SPSS) (19th edition) was used for descriptive statistics. Means, percentages and frequencies were used to summarize and categorize the information gathered.

The binomial logit model was used to analyze the factors affecting farmers' decisions to adapt to climate change or not to adapt $[6,12,20]$. In this case, the dependent variable was dichotomous i.e. farmers' decision to adapt or not adapt to climate change. According to Muzamhindo [20] and Fosu-Mensah [21], the binary logit model is appropriate in this case because it considers the relationship between a binary dependent variable and a set of independent variables. In its reduced form, the binary logit is expressed as follows [12,20]:

$$
Y=f(X 1, X 2, \ldots, X 6)
$$

where $\mathrm{Y}$ is the adaptation status ( $1=$ farmers who adapted, $0=$ farmers who did not adapt).

The multinomial logit model was used to determine the factors influencing the choice of farmers to use a particular method of adaptation to climate change $[6,22,23]$. In this model, the dependent variable was multinomial with as many categories as the number of climate change adaptation methods inventoried in the study area. The reduced form of the model is as follows [6]:

$$
Y i=f(X 1, X 2, \ldots, X 6)
$$

where $\mathrm{Yi}$, the polychotomic dependent variable, is the adaptation method chosen by the producer and $\mathrm{X} 1$ to $\mathrm{X} 6$ are the explanatory variables. Based on the data collected on the adaptation strategies developed by farmers in the study area, the dependent variable (Yi) is coded 1 for "no adaptation," 2 for "Crop-livestock diversification," 3 for "Use of improved varieties, chemical fertilizers and pesticides," 4 for "Agroforestry and perennial plantation (oil palm, orchard, tree species)," 5 for "Diversification of income-generating activities" and 6 for "Multiple coping strategies." The explanatory variables 
include: $\mathrm{X} 1=$ Farming experience, $\mathrm{X} 2=$ Farm size, $\mathrm{X} 3=$ education level, $\mathrm{X} 4=$ Gender, $\mathrm{X} 5=$ Percentage of farm income and X6 = Belonging to a farmers' organization.

Tazeze [22] gave more details on the hypothetical relationships between these variables and adaptation to climate change. The standardization of a category, defined as "base category" or "reference state," was used to estimate the model of multinomial logical regression [6,22]. In this study, the category "no adaptation" was used as the base category.

\section{Results}

\subsection{Socioeconomic Characteristics of Household Heads}

The socioeconomic characteristics of respondents were collected. These included gender, age, occupation, farming experience, farm size and educational level. The study sample was dominated by men $(76.7 \%)$. Thus, the heads of agricultural households were predominantly men. Indeed, female heads of households were most often widows or divorced. The age of farmers varied between 25 and 67 years ( 46 years on average) and $55.8 \%$ of them were illiterate. Agriculture (crop production) was the main activity of the respondents $(75 \%)$. The remainder consisted of livestock farmers $(16.7 \%)$ and food processors (8.3\%). Respondents had an average of 16.57 years farming experience; the most experienced had 40 years farming experience and the least, three years farming experience.

The farm size varied from 0.75 to 10 ha (4.74 ha on average). Only $43.3 \%$ of respondents had less than 5 ha. This reflects the importance of agriculture in the study area. The majority of farmers $(78.3 \%)$ belonged to a farmers' organization (a village association or cooperative or a communal union of farmers). Very few $(8.3 \%)$ had access to funding (microcredit) from regularly registered microfinance institutions. Thus, they were struggling to finance their activities. The majority of them $(65 \%)$ received extension services (support-advice, capacity building, training, farmer field school).

\subsection{Smallholder Farmers' Perception of Climate Change}

This section analyzes farmers' perceptions of climate change. Analysis of the data showed that farmers clearly perceive climate change. About $90.8 \%$ of respondents claimed that the climate had changed. To the question of what these changes consist of, different answers were recorded and we made a typology of the changes observed by the farmers. The main changes observed were: rainfall disturbances (rainfall delays, early cessation, bad rainfall distribution etc.); shortening of the small dry season, increasing of temperature, and, sometimes, violent winds and other extreme events such as floods in some areas (see Figure 2).

Rainfall disturbances were perceived by $89 \%$ of respondents. In this region, like other regions of the country, since agriculture is rainfed and the agricultural calendar is adapted to the rainfall regime, it is quite normal for farmers to perceive any change in the rainfall regime. However, disturbances in precipitation were perceived differently.

When farmers were asked how the rainfall patterns had changed, all the respondents had observed a number of changes in the overall climate pattern (Figure 3). Most farmers claimed that the rainy season started later $(75.8 \%)$ and stopped earlier $(70 \%)$. The majority of respondents $(75.8 \%)$ noted a delay in the onset of the rainy season. Sixty percent of respondents claimed that the rainy season length had decreased. Regarding rainfall, $45 \%$ of respondents noted an increase in rainfall amount and $42.5 \%$ claimed that the rainfall amount had decreased.

Changes were perceived in temperature and droughts (Figure 4). Almost $64 \%$ noticed an increase of the length of the long dry season and $85 \%$ of farmers claimed that the small dry season was shortening. Most of the respondents observed an increase of temperature. 


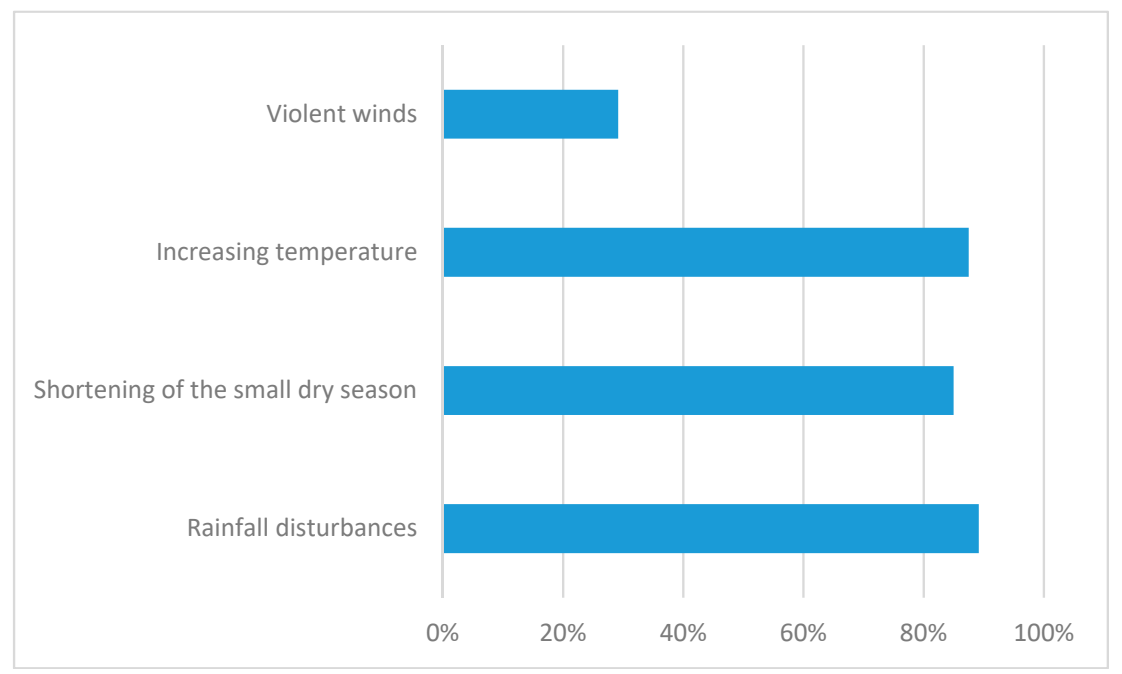

Figure 2. Farmers' perception of climate change.

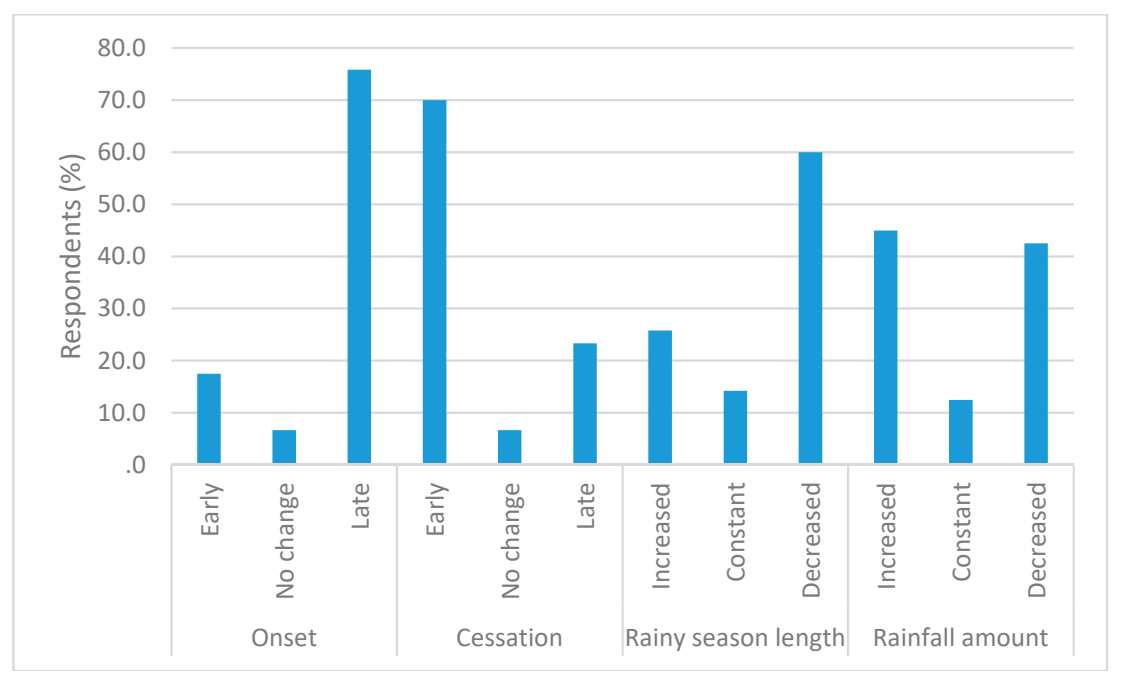

Figure 3. Farmers' perception of changes in rainfall patterns.

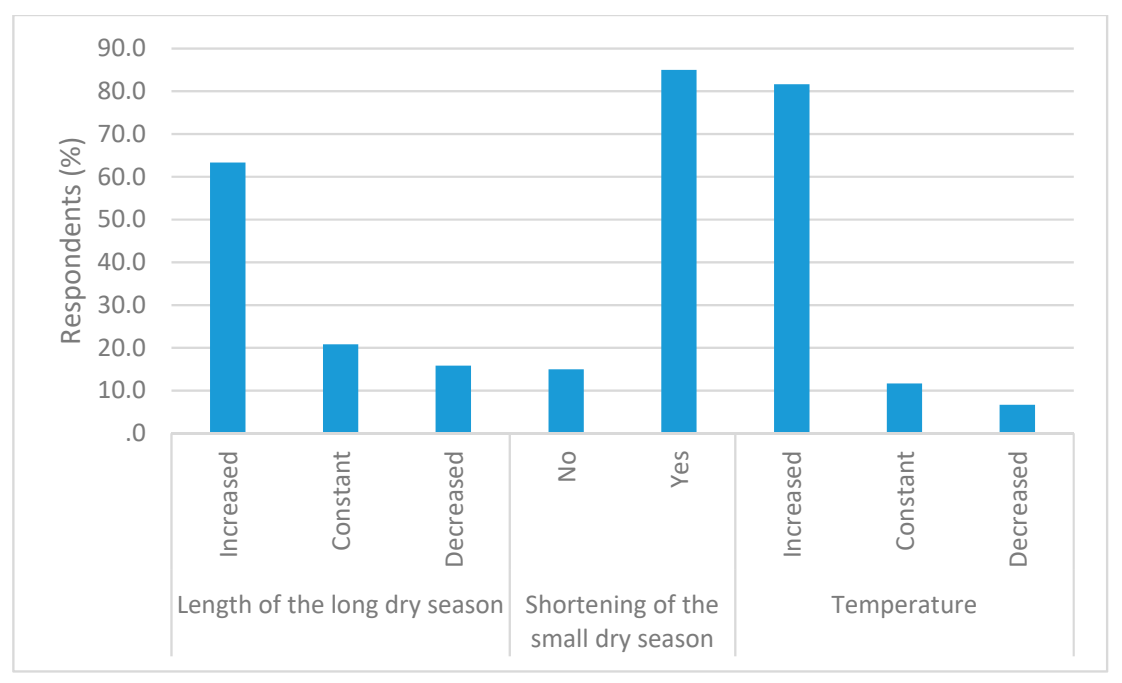

Figure 4. Farmers' perception of changes in temperature and drought. 


\subsection{Effects of Climate Change on Agriculture and Livelihood}

Climate change is having an effect on agriculture and livelihood. Table 1 shows that only $15 \%$ of the respondents disagreed that climate change led to crop/livestock infestation and diseases, while $65.83 \%$ strongly agreed with the assertion. The findings also revealed that $33.8 \%$ of the farmers reported that climate change is responsible for the increase in land degradation, while only $18.33 \%$ disagreed. It is therefore not surprising that their strategies are based on pest and disease control and land management.

Of the respondents, $87.5 \%$ reported that climate change led to a decrease in crop yields. In addition, $90 \%$ of the respondents claimed that increased food costs are an effect of climate change. The implication could be that the respondents developed strategies to improve productivity of food or to secure income in the study area.

Almost $46 \%$ of smallholder farmers disagree that climate change has led to rural-urban migration while $17.5 \%$ were neutral.

Table 1. Distribution of respondents by perceived effect of climate change $(n=120)$.

\begin{tabular}{|c|c|c|}
\hline Farmers' Perception of Climate Change Effect & Frequency & Percentage $(\%)$ \\
\hline \multicolumn{3}{|l|}{ Increased crop/livestock pests and diseases } \\
\hline Strongly agreed & 79 & 65.8 \\
\hline Agreed & 23 & 19.2 \\
\hline No response & 0 & 0 \\
\hline Disagree & 18 & 15 \\
\hline Strongly disagreed & 0 & 0 \\
\hline \multicolumn{3}{|l|}{ Increased land degradation } \\
\hline Strongly agreed & 56 & 46.7 \\
\hline Agreed & 31 & 25.8 \\
\hline No response & 11 & 9.2 \\
\hline Disagree & 16 & 13.3 \\
\hline Strongly disagreed & 6 & 5 \\
\hline \multicolumn{3}{|l|}{ Decrease in yields } \\
\hline Strongly agreed & 67 & 55.8 \\
\hline Agreed & 38 & 31.7 \\
\hline No response & 2 & 1.7 \\
\hline Disagree & 11 & 9.2 \\
\hline Strongly disagreed & 2 & 1.7 \\
\hline \multicolumn{3}{|l|}{ Increase in food costs } \\
\hline Strongly agreed & 51 & 42.5 \\
\hline Agreed & 57 & 47.5 \\
\hline No response & 1 & 0.8 \\
\hline Disagree & 5 & 4.2 \\
\hline Strongly disagreed & 6 & 5 \\
\hline \multicolumn{3}{|l|}{ Increased rural-urban migration } \\
\hline Strongly agreed & 13 & 10.8 \\
\hline Agreed & 31 & 25.8 \\
\hline No response & 21 & 17.5 \\
\hline Disagree & 19 & 15.8 \\
\hline Strongly disagreed & 36 & 30 \\
\hline
\end{tabular}

Source: Survey result.

\subsection{Farmers' Strategies for Adaptation to Climate Variability and Climate Change}

Farmers have adopted different strategies to adapt to climate change and climate variability. Farming is the main occupation for the majority of the sample households. Based on the household survey data collected from 120 households, $90.8 \%$ of farmers had observed changes in climate, while $85 \%$ of them reacted to this change. This is important, because, as reported by Mustapha [12], adaptation to climate change is a process that initially requires farmers to perceive that the climate 
has changed and then identify the necessary adaptations to be implemented. When the respondents were asked if they have responded through adaptation to reduce the impact of climate change, about $85.0 \%$ reported that they are using different adaptation strategies to reduce the negative impact of climate change. These include: "Crop-livestock diversification and other good practices (mulching, organic fertilizer)," "Use of improved varieties, chemical fertilizers and pesticides," "Agroforestry and perennial plantation (oil palm, orchard, tree species)" and "Diversification of income-generating activities" (Table 2). Most of respondents (24.2\%) used these strategies in combination.

Table 2. Adaptation strategies used by farmers.

\begin{tabular}{lcc}
\hline \multicolumn{1}{c}{ Adaptation Strategies } & Frequency & Percentage (\%) \\
\hline No adaptation strategies & 17 & 14.2 \\
Crop-livestock diversification and other good practices (mixed & 44 & 36.7 \\
cropping, crop rotation, mulching, organic fertilizer) & 46 & 38.3 \\
Use of improved varieties, chemical fertilizers and pesticides & 43 & 35.5 \\
Agroforestry and perennial plantation (oil palm, orchard, tree species) & 17 & 14.2 \\
Diversification of income-generating activities & & \\
\hline
\end{tabular}

Source: Survey result. Note that a farmer can adopt more than one adaptation strategy.

Crop-livestock diversification (mixed cropping, intercropping and crop rotation) is a common practice in the Zou Department in general and in the study area in particular. From focus group discussions with farmers, it was revealed that farmers had a wide knowledge of the advantages of mixed cropping.

These include: reduction of the effects of adverse weather conditions (drought, erosion, etc.), slowdown the spread of pests and diseases in the growing season, reduction in input requirements and increasing of yields. The mixed cropping frequently mentioned by respondents were: maize-cassava, maize-groundnut, maize-bean, maize-bean-cassava. It should also be noted that farmers associate these practices with a concern for preserving food and nutritional security of the household. Farmers are seeking to increase the chances of guaranteeing a minimum of products after harvesting. "If one fails, the other can succeed," said the respondents. About $36.7 \%$ of respondents used crop-livestock diversification as an adaptation strategy to reduce the adverse effect of climate change on farm productivity (Table 2). Some of the respondents also used mulching and organic fertilizers in addition to crop-livestock diversification. In addition, some farmers have adopted small ruminant and poultry farming to diversify their sources of income. These livestock are mainly fed with crop residues.

One of the major problems that farmers are facing in the study area is the increase of crop-livestock pests and diseases. Thus, $38.3 \%$ of farmers used improved crop varieties as an adaptation strategy to reduce the adverse effect of climate change. Farmers used drought tolerant and short maturing varieties of crops. They also used chemical fertilizers to increase crop productivity and pesticides to control pests and diseases.

The growing of perennial plants is a practice for supporting farm income. According to the respondents, these plantations address a concern of securing household income. Oil palm, citrus and teak trees are the most perennial species cultivated by farmers. This strategy is interesting for the minimization of agroclimatic risks because arboriculture is a good bulwark against climate change. It is worth noting that there were also some farmers who practice agroforestry (integrate trees and crops); and these farmers had a deep knowledge of the benefits of such practice: preventing soil erosion, reducing losses of water, availability of organic matter and nutrients, reducing the amount of agricultural insect pests and associated diseases etc. About $35.5 \%$ of respondents adopted this strategy to reduce the adverse effect of climate change on their farm.

The instability of farm incomes in the study area is not negligible. Some households diversify their income-generating activities to earn additional funds or stabilize their incomes. Generally, they turn to off-farm activities. Diversification of income-generating activities was used by $14.2 \%$ of households to secure their incomes. 


\subsection{Combination of Adaptation Strategies}

The adaptation strategies developed by farmers to cope with climate change can be used in combination. About $24.2 \%$ of respondents used these strategies in combination. This section analyzes how respondents combined agronomic strategies to adapt to climate change. Four kinds of combination were identified (Table 3).

Table 3. Combination of agronomic strategies.

\begin{tabular}{|c|c|c|c|}
\hline Adaptation Strategies & $\begin{array}{c}\text { Crop-Livestock } \\
\text { Diversification and } \\
\text { Other Good Practices }\end{array}$ & $\begin{array}{c}\text { Use of Improved Varieties, } \\
\text { Chemical Fertilizers and } \\
\text { Pesticides }\end{array}$ & $\begin{array}{c}\text { Agroforestry and } \\
\text { Perennial } \\
\text { Plantation }\end{array}$ \\
\hline $\begin{array}{l}\text { Crop-livestock diversification } \\
\text { and other good practices }\end{array}$ & & \multirow[t]{3}{*}{10} & 5 \\
\hline $\begin{array}{c}\text { Use of improved varieties, } \\
\text { chemical fertilizers and } \\
\text { pesticides }\end{array}$ & & & 2 \\
\hline $\begin{array}{l}\text { Agroforestry and perennial } \\
\text { plantation }\end{array}$ & & & \\
\hline Mix of three strategies & & 12 & \\
\hline
\end{tabular}

Some combinations may seem contradictory. For example, "Crop-livestock diversification and other good practices" and "Use of improved varieties, chemical fertilizers and pesticides" or "Use of improved varieties, chemical fertilizers and pesticides" and "Agroforestry and perennial plantation." However, for farmers, each strategy has a specific purpose, although the ultimate and common goal is adaptation to climate change.

Crop-livestock diversification aims to allow farmers to have various products at harvest and to minimize losses due to climate change. Indeed, one of the manifestations of climate change is rainfall disturbance. As this phenomenon has influenced the agricultural calendar, many farmers do not know which crop to grow on what date. Crop-livestock diversification therefore remains a way to increase the chances of having produce at the end of the season. This practice, apart from its agronomic advantages and the fact that it offers a rich and varied landscape during the agricultural season, contributes to the preservation of food and nutritional security of the household.

Crop-livestock diversification and other good practices (mixed cropping, intercropping and crop rotation) have the advantage of slowing down the spread of pests and diseases in the growing season, reducing input requirements and increasing yields. It is therefore questionable why some farmers combine this practice with the use of chemical fertilizers and pesticides. First, it should be noted that certain crops, whether in combination or in monoculture, require minimal pesticide application to ensure production at harvest. This is the case, for example, with cowpea. Because organic pesticides are not widely known, farmers use chemical pesticides to control pests and diseases. However, doses are limited. This applies to chemical fertilizers that are sometimes not even used when farmers practice some crop rotation, especially when maize comes after a leguminous plant. Therefore, it is easier to understand why farmers combine crop-livestock diversification and the use of chemical fertilizers and pesticides (and improved varieties).

The growing of fruit species and oil palm is an agricultural income support practice. Because the perennial species are less sensitive to climatic shocks, they are grown to secure the household income. Revenues come from the sale of fruit and are more regular than from crops. Some growers, instead of growing fruit species, prefer forest species (Tectona grandis, Acacia auriculiformis, Eucalyptus sp.). In both cases, the practice is to grow crops between the rows of perennial plants for the first three to five years. What is interesting in this practice is that farmers opt for improved varieties, especially for fruit species and oil palm. These improved varieties have some input requirements. These inputs, especially the fertilizers that are given to these perennial plants, can benefit the crops that are grown between the tree rows and vice versa. These practices combine easily with the first two described above. 


\subsection{Determinants of Farmers' Choice of Adaptation Strategies}

The binary logit regression results are presented in Table 4 . The logistic regression model was statistically significant $(p<0.05)$. The model explained $79 \%$ (Nagelkerke $\mathrm{R}^{2}$ ) of the variance in farmers' decisions to adapt to climate change and correctly classified $93.3 \%$ of decisions.

From the binary logit regression results, educational level and farming experience positively and significantly influence farmers' decisions to adapt to climate variability. The results indicate that only the most experienced and well educated are able to define adaptation strategies to climate change (Table 4).

Table 4. Determinants of the decision to adapt to climate change by farmers.

\begin{tabular}{ccc}
\hline Explanatory Variables & Odds Ratio & Std. Err. \\
\hline Gender & 0.485 & 0.622 \\
Educational level & $10.462 * *$ & 10.057 \\
Farming experience & $1.442^{* * *}$ & 0.18 \\
Farm size & 1.525 & 0.589 \\
Belonging to farmers' organization & 5.292 & 6.636 \\
Percentage of farm income & 1.009 & 0.052 \\
Constant & 0.001 & 0.004 \\
\hline Number of respondents $=120$ \\
Prob $>$ Chi ${ }^{2}=0.0000$ \\
Log likelihood $=-14.765105$ \\
Pseudo $\mathrm{R}^{2}=0.7089$ \\
\% of correct prediction $=93.3 \%$ \\
\hline$* * * * *$ Significant at $5 \%$ and $1 \%$ level respectively.
\end{tabular}

The analysis of multinomial logical regression to determine the factors influencing the choice of farmers to use a particular method of adaptation to climate change revealed that farming experience and educational level significantly affected the use of different methods of adaptation (Table 5).

- Farming experience: The results indicate that farming experience positively and significantly affected the choice of all strategies except the diversification of income-generating activities. The household head is more experienced and is expected to acquire more competence in weather forecasting. This helps to increase the likelihood of practicing different adaptation strategies to climate change.

- Educational level: This factor had a positive and strong effect on the dependent variable. All adaptation strategies are influenced by this factor. This can be explained by the fact that literate farmers are able to search for information and make choices based on their preference and level of information gathered.

- Gender of household head: The results indicate that being female, as a household head, increases the chance to choose diversification of income-generating activities as adaptation to climate change. The possible reason is that much of the farming activities are done by men, while women are more involved in processing or off-farm activities like trade.

- Farm size: Farm size had a positive and significant impact on multiple coping strategies. The larger the farm, the more farmers opted for the combination of several coping strategies: agroforestry and perennial plantation, crop-livestock diversification, improved varieties etc.

This model has limitations due to the choice of questions and the data, which induces the explaining variables. The choice of the data collected is based on the state of the art in the literature and on our empirical knowledge of the geographical and socioeconomic context of the country and the precise region. Our research could have explored further possible variables if more time and human resources were available. In particular, a round of preliminary exploratory qualitative interviews would have allowed screening for new items to search and collect as explanatory variables. 
Table 5. Determinants of a farmer's choice to use a specific climate change adaptation strategy.

\begin{tabular}{|c|c|c|c|c|c|c|c|c|c|c|}
\hline \multirow[t]{2}{*}{$\begin{array}{l}\text { Explanatory } \\
\text { Variables }\end{array}$} & \multicolumn{2}{|c|}{$\begin{array}{c}\text { Crop-Livestock } \\
\text { Diversification and Other } \\
\text { Good Practices }\end{array}$} & \multicolumn{2}{|c|}{$\begin{array}{c}\text { Use of Improved Varieties, } \\
\text { Chemical Fertilizers and } \\
\text { Pesticides }\end{array}$} & \multicolumn{2}{|c|}{$\begin{array}{c}\text { Agroforestry and Perennial } \\
\text { Plantation }\end{array}$} & \multicolumn{2}{|c|}{$\begin{array}{c}\text { Diversification of } \\
\text { Income-Generating } \\
\text { Activities }\end{array}$} & \multicolumn{2}{|c|}{ Multiple Coping Strategies } \\
\hline & B (coef) & Sig ( $p$-value) & B (coef) & Sig ( $p$-value) & B (coef) & Sig (P-value) & B (coef) & Sig (P-value) & Sig (P-value) & Sig (P-value) \\
\hline $\begin{array}{l}\text { Farming } \\
\text { experience }\end{array}$ & 0.314 & 0.006 * & 0.328 & $0.004 *$ & 0.384 & $0.001 *$ & 0.020 & 0.892 & 0.331 & $0.004 *$ \\
\hline Farm size & -0.002 & 0.996 & 0.232 & 0.564 & 0.603 & 0.139 & 0.696 & $0.103 * *$ & 0.888 & $0.030 *$ \\
\hline $\begin{array}{l}\text { Percentage of } \\
\text { farm income }\end{array}$ & -0.055 & 0.257 & -0.004 & 0.927 & -0.014 & 0.771 & 0.052 & 0.324 & 0.001 & 0.986 \\
\hline Educational level & 2.009 & $0.019 *$ & 2.300 & $0.007 *$ & 2.211 & $0.010 *$ & 1.755 & $0.040 *$ & 2.249 & $0.009 *$ \\
\hline Gender & -1.687 & 0.215 & -1.688 & 0.241 & -2.041 & 0.189 & 4.203 & $0.035 *$ & -1.577 & 0.304 \\
\hline $\begin{array}{l}\text { Belonging to } \\
\text { farmers' } \\
\text { organization }\end{array}$ & -0.183 & 0.877 & -0.920 & 0.462 & -1.607 & 0.230 & -3.345 & $0.072 * *$ & -0.853 & 0.502 \\
\hline Base category & \multicolumn{10}{|c|}{ No adaptation } \\
\hline $\begin{array}{l}\text { Number of } \\
\text { observation }\end{array}$ & \multicolumn{10}{|c|}{120} \\
\hline LR Chi ${ }^{2}$ & \multirow{2}{*}{\multicolumn{10}{|c|}{$\begin{array}{c}148.526 \\
-135.602\end{array}$}} \\
\hline Log likelihood & & & & & & & & & & \\
\hline Prob $>\mathrm{Chi}^{2}$ & \multicolumn{10}{|c|}{0} \\
\hline
\end{tabular}




\section{Discussion}

\subsection{Farmers' Perceptions of and Adaptation Strategies to Climate Change}

The results of this study on the perceptions and adaptation strategies of farmers in the Zou Department of Benin show that farmers are well aware of climate change, as more than $90 \%$ of farmers interviewed perceived a change in the climate. Several studies in Africa $[5,6,12,20,21,24]$ and around the world have already yielded similar results. The main changes observed are: rainfall disturbances (rainfall delays, early cessation, bad rainfall distribution etc.), shortening of the small dry season, increasing temperature, sometimes violent winds and other extreme events such as floods. The same perceptions have been reported from several studies in Benin $[6,17,25]$, Niger [15], Nigeria [12,26] and Kenya [16].

The shortening of the small rainy season has a real impact on cropping systems in the study area. Indeed, this short dry season allows farmers to dry harvests from the great rainy season. However, this shortening of the small dry season poses a real problem for conservation of cereals and leguminous plants from the great rainy season. This phenomenon has led farmers to rethink their cropping systems (choice of crops, choice of varieties according to the length of their cycle, crop management, etc.). A similar situation in Tanzania and Senegal has been reported [27].

The majority of farmers who have perceived (90.8\% of respondents) climate change have developed an adaptation strategy ( $85 \%$ of respondents). This is contrary to the findings of Fosu-Mensah [21] who showed that only a few farmers have developed adaptation strategies. Two hypotheses could explain this difference. First, this difference could be due to the socioeconomic characteristics of the respondents. The more experienced or literate farmers are, the better they adopt climate change adaptation strategies. Unfortunately, Fosu-Mensah [21] did not present the socioeconomic characteristics of his respondents in his article so that we can analyze the differences.

The second hypothesis that seems to be most likely is that there is now enough communication and training on climate change adaptation strategies, so farmers have begun to adopt these strategies. Indeed, Fosu published his article in 2010. The data have evolved a lot since then.

Comparing the results of this study with those already carried out in Benin, the same trend emerges but with a clear improvement. In fact, more producers are adopting strategies for adapting to climate change today.

The main adaptation strategies of farmers identified include "Crop-livestock diversification," "Use of improved varieties, chemical fertilizers and pesticides," "Agroforestry and perennial plantation (oil palm, orchard, tree species)" and "Diversification of income-generating activities." Similar findings were reported by several authors $[15,16,28]$. The various strategies adopted by farmers showed that they are seeking to strengthen their farming systems through agrobiodiversity. Whatever the choice, the farmers aim to ensure a minimum harvest for their own food security. This is why maize (most consumed cereal) appears in all mixed cropping in the area. In fact, the yields of the crops grown in association are often less affected by climatic accidents [27].

The results of factors influencing the choice of a specific adaptation strategy suggest that farming experience, educational level, gender and farm size are the most significant factors affecting the adaptation choice of farmers. Farming experience facilitates the identification and implementation of any adaptation strategy. This finding is in line with previous work $[6,22,29]$. The educational level has significantly influenced the choice of all adaptation strategies. This confirmed the results of Assoumana [15] and Tazeze [22]. According to Kumari [30], educated and experienced farmers are expected to have more knowledge and information about climate change and the agronomic practices that they can use in response. Farm size determines the decision to combine multiple strategies to cope with climate change. This is confirmed by Sani \& Chalchisa [29] who reported that large-scale farmers are more likely to adapt to climate change because they have more capital and resources. 


\subsection{Implications of Farmers' Choices}

Farmers' choices on adoption of given adaptation strategies could have two purposes; either for expected profit or avoiding risk [16]. All strategies developed by farmers to adapt to climate change fit into these two purposes. In this section, we analyzed the agroecological implications and the sustainability of the strategies developed.

The mainstream strategy to cope with climate change is the use of improved variety, chemical fertilizers and pesticides. However, important studies have revealed the negative impacts of chemical fertilizers and pesticides (especially the over use) on the environment [30]. Given the increase in agricultural pests and diseases, some farmers have no choice but must adapt in learning more sustainable farming practices, like organic farming or integrated pest management, because long-term effects of high-input agriculture are contamination of soils and water, water scarcity and losses in biodiversity. According to Kumari [30], they all have direct negative consequences on animal and human health.

Crop diversification is the practice of cultivating more than one variety of crop belonging to the same or different species in a given area in the form of rotations and or intercropping. Farmers can face growing stress from climate change by implementing a diversified agricultural system which may be a productive way to build resilience into agricultural systems [31]. Crop diversification is perceived as one of the most ecologically feasible, cost effective and rational ways of reducing uncertainties in agriculture especially among smallholder farmers [32]. The results of this study show that many farmers use this method to adapt to climate change. Crop diversification improves soil fertility, controls for pests and diseases and brings about yield stability, nutrition diversity and health [31,32]. It can also serve as a superior substitute for the use of chemicals to maintain soil fertility and control pests. Certain crops in a rotation system, especially pigeon pea and mucuna, are reputed to control weeds and improve soil fertility [33]. Diversified cropping systems, in general, tend to be more agronomically stable and resilient [31,32]. In addition, several studies have shown that crop diversification, especially in food crops, has positive effects on children's nutrition [34,35].

Another major strategy is agroforestry and perennial plantation. Many studies have shown that agroforestry may offer many economic and environmental benefits [36-39]. According to Zoysa [39], agroforestry has an important role in climate change adaptation by enhancing resilience to climate impacts on farming systems. Torquebiau [40] reported that agroforestry has a double potential to address climate change issues: greenhouse gas mitigation strategy through carbon sequestration and sustainable adjustment to changing conditions (because agroforestry systems can be called perennial farming systems). More than an adaptation strategy, agroforestry is a mitigation strategy. Agroforestry is a landscape-scale approach, thus favors synergy between adaptation and mitigation [40]. Apart from its socioeconomic benefits [38], agroforestry, through its effects on soil conservation, protection of biodiversity, carbon sequestration $[40,41]$ is the most sustainable strategy.

\subsection{Barriers to Effective Adaptation}

Several studies carried out in Africa pointed out many barriers, which challenged the ability of farmers to adapt to climate change. The main barriers identified are: institutional factors, access to credit, lack of information and irregularity of extension services [15,29,42].

Juana et al. [42] reported that the institutional factors that influence adoption of new technologies are access to information via extension services (climate information and production technologies) and access to credit. According to the same author, farmers who have significant extension contacts have better chances of being aware of changing climatic conditions as well as adaptation measures in response to the changes in these conditions. This is confirmed by the findings of Assoumana [15]. Sani \& Chalchisa [29] reported that insufficient access to inputs, lack of knowledge about other adaptation options, no access to water, lack of credit, lack of information about climate change, high cost of adaptation and insecure property rights were the main climate change adaptation constraints. 


\subsection{Influence of Agricultural Policies}

The evidence that climate change will adversely affect agriculture in Benin has become a crucial challenge for sustainable development in the country. This challenge is composed of the likely impacts on ecosystem services, agricultural production and livelihoods. Generally, losses in the agriculture sector due to climate change has economy wide consequences, like loss in gross domestic output, a decline in the income/consumption of the most vulnerable population; hence, a general deterioration in household welfare [42]. To dampen the adverse consequences of climate change, Benin agricultural policies, like in Western Africa, have focused on agricultural intensification through the use of technological packages (improved varieties, diffusion of chemical fertilizers and pesticides, etc.). In Benin, only the cotton sector has benefited from subsidies (fertilizers and pesticides) from the state until the decline in its production in the 2000s. Thus, in order for farmers to benefit from the subsidized input, they were obliged to grow cotton. This put farmers in a precarious situation.

However, after the decline of the Benin cotton sector, agricultural diversification has become a policy priority. Therefore, several projects and programs have been implemented for that purpose. Besides this new agricultural diversification policy, improving productivity remains a priority for the state. To improve farm productivity, extension services provide farmers with information on the use of certified improved seeds, chemical fertilizers and pesticides. The overall cost of implementing such advice in the case of maize, for example, is so high that a poor harvest would be catastrophic for a farmer and his family.

However, for a farming family, the goal is not necessarily to have the best yields but rather to generate sufficient income that will support the family needs [27].

In the interviews conducted for our research, some farmers were clearly seeking a certain balance between extension service advice and their know-how. Others were downright reluctant to adopt technology packages.

On the other hand, many of the health impacts of food systems trace back to specific industrial food and farming practices, e.g. intensive livestock production and chemical-intensive agriculture [43]. In this context, diversified, agroecological systems refer to a model based on diversifying farms and farming landscapes, replacing chemical inputs with organic matter, optimizing biodiversity and stimulating interactions between different species, as part of holistic strategies to build long-term fertility, healthy agroecosystems and secure livelihoods [43]. This approach has major advantages and can provide strong and stable yields, health-promoting food and farming systems, environmental resilience and secure farming livelihoods, thereby succeeding where current food systems are failing [43].

Indeed, agriculture has to simultaneously address three intertwined challenges: ensuring food security through increased productivity and income, adapting to climate change and contributing to climate change mitigation. To address these challenges, food systems have to become, at the same time, more efficient and resilient, at every scale from the farm to the global level [44]. It is precisely to articulate these changes that the Food and Agriculture Organization (FAO) has forged the concept of climate-smart agriculture (CSA). CSA is "agriculture that sustainably increases productivity, enhances resilience (adaptation), reduces/removes greenhouse gas (GHG)s (mitigation) where possible and enhances achievement of national food security and development goals" [44,45]. In Benin, agricultural sectors must become climate-smart to successfully tackle current food security and climate change challenges. CSA contributes to food security, by addressing different aspects of current and projected climate change impacts through adaptation and mitigation actions. While agriculture contributes significantly to climate change, it also provides opportunities for adapting to and mitigating, climate change effects $[44,45]$. In addition, the FAO is conducting several actions for agroecology around the world and in sub-Saharan Africa in particular. As a set of practices, agroecology seeks sustainable farming systems that optimize and stabilize yields. It is an approach that will help address the challenge of ending hunger and malnutrition in all its forms in the context of climate change adaptation.

It is in this context that the FAO organized the first international symposium on agroecology in 2014 and five regional symposiums that took place between 2015 and 2016; and provided a space for 
discussion and the opportunity to share experiences, build a consistent database of agroecological initiatives. To bring agroecology on a larger scale, in April 2018 the FAO will host the second FAO International Symposium on Agroecology: Agroecology for Sustainable Development Goals (SDGs)—scaling up.

\section{Conclusions}

This study revealed that farmers in the Zou Department are well aware of climate change and have a good perception of both its effects and impacts on agricultural production. Thus, they have adopted different strategies to adapt to these changes. The main adaptation strategies of farmers identified include "Crop-livestock diversification," "Use of improved varieties, chemical fertilizers and pesticides," "Agroforestry and perennial plantation (oil palm, orchard, tree species)" and "Diversification of income-generating activities." Several factors such as farming experience, educational level, farm size and gender determine the choice of adaptation strategy. However, there are some barriers which challenged the ability of farmers to cope with climate change.

This paper also showed that a farmer's ability to adapt to climate change depends on his perception of the phenomenon, the need to provide solutions and the opportunities, which are given to him.

These findings have public policy implications. Governments should include climate change adaptation policies in their development agenda. The findings of this study should help policymakers to better think and plan agricultural policies in terms of adaptation to climate change. Indeed, choices made in terms of public policies can be decisive. Some agricultural policies may exacerbate the impact of climate change, while others may be effective in increasing and securing farmers' incomes [27]. The design and implementation of any climate change policy requires adequate knowledge about the level of vulnerability, the existing knowledge the population has about the risks they are exposed to, the adaptation practices adopted, the existing capacity to adapt and the perceived barriers to adaptation [42]. This study provides evidence to agree with the conclusion of Cochet et al. [27], that, to be effective, agricultural policies in terms of adaptation to climate change should integrate at the same time:

- Equitable access to the means of production;

- Dissemination of technical levers to increase yields per hectare for the greatest number;

- Sufficiently stable and remunerative levels of agricultural prices;

- An endogenous growth strategy, initially favoring food sovereignty driven by family farming.

Author Contributions: Roland Fadina and Dominique Barjolle conceived and designed the methodology, Roland Fadina performed the survey and analyzed the data; Roland Fadina and Dominique Barjolle wrote the paper.

Conflicts of Interest: The authors declare no conflict of interest.

\section{References}

1. World Bank. Benin Presentation. Available online: http://www.banquemondiale.org/en/country/benin/ overview (accessed on 12 October 2016).

2. Groupe D'experts Intergouvernemental sur L'évolution du Climat. Bilan 2007 des changements climatiques. In Contribution des Groupes de Travail I, II et III au Quatrième Rapport D'évaluation du Groupe D'experts Intergouvernemental sur L'évolution du Climat; GIEC: Geneva, Switzerland, 2007; 103p.

3. Intergovernmental Panel on Climate Change. Climate Change 2007: Impacts, Adaptation and Vulnerability. Contribution of Working Group II to the Fourth Assessment Report of the Intergovernmental Panel on Climate Change; Cambridge University Press: Cambridge, UK, 2007; 976p.

4. Food and Agriculture Organization. FAO BENIN: Cadre de Programmation Pays, 2012.

5. Gnangle, P.C.; Egah, J.; Baco, N.M.; Gbemavo, C.; Glèlè, R.; Sokpon, N. Perceptions locales du changement climatique et mesures d'adaptation dans la gestion des parcs à karité au Nord-Bénin. Int. J. Biol. Chem. Sci. 2012, 6, 136-149. [CrossRef] 
6. Loko, Y.L.; Dansi, A.; Agre, A.P.; Akpa, N.; Dossou-Aminon, I.; Assogba, P.; Dansi, M.; Sanni, A.; Akpagana, K. Perceptions paysannes et impacts des changements climatiques sur la production et la diversité variétale de l'igname dans la zone aride du nord-ouest du Bénin. International. J. Biol. Chem. Sci. 2013, 7, 672-695. [CrossRef]

7. Assouma Imorou, A. Analyse Socio-économique Selon le Genre des Effets de la Variabilité Climatique sur les Ménages Riziculteurs du Centre et du Nord-Ouest du Bénin. Master's Thesis, Université D'Abomey-Calavi, Abomey-Calavi, Benin, 4 April 2014.

8. Houessou, D. Vulnérabilité des Communautés d'éleveurs du Centre-Bénin à la Variabilité et aux Changements Climatiques. Master's Thesis, Université d'Abomey-Calavi, Abomey-Calavi, Benin, 29 March 2014.

9. Thoto, F. Vulnérabilité des Communautés de Pêcheurs du Sud—Ouest Bénin à la Variabilité et aux Changements Climatiques. Master's Thesis, Université d'Abomey-Calavi, Abomey-Calavi, Benin, 29 March 2014.

10. INSAE (Institut National de la Statistique et de l'Analyse Economique). Annuaire Statistique 2000-2004; INSAE: Abomey-Calavi, Benin, 2004.

11. Sombroek, W.G.; Gommes, R. L'énigme: Changement de climat-Agriculture. In Changements du Climat et Production Agricole; FAO, Ed.; FAO: Rome, Italy, 1997; p. 472.

12. Mustapha, S.B.; Sanda, A.H.; Shehu, H. Farmers' Perception of Climate Change in Central Agricultural Zone of Borno State, Nigeria. J. Environ. Earth Sci. 2012, 2, 21-28.

13. Simelton, E.; Quinn, C.H.; Batisani, N.; Dougill, A.J.; Dyer, J.C.; Fraser, E.D.G.; Mkwambisi, D.; Sallu, S.; Stringer, L.C. Is rainfall really changing? Farmers' perceptions, meteorological data, and policy implications. Clim. Dev. 2013, 5, 123-138. [CrossRef]

14. Comoé, H. Contribution to Food Security by Improving Farmers' Responses to Climate Change in Northern and Central Areas of Côte D'ivoire; ETH: Zurich, Switzerland, 2013.

15. Assoumana, B.T.; Ndiaye, M.; Puje, G.; Diourte, M.; Graiser, T. Comparative Assessment of Local Farmers' Perceptions of Meteorological Events and Adaptations Strategies: Two Case Studies in Niger Republic. J. Sustain. Dev. 2016, 9, 118-135. [CrossRef]

16. Gebreeyesus, K.A. Impact of Climate Change on the Agro-ecological Innovation of Coffee Agroforestry Systems in Central Kenya. Ph.D. Thesis, SupAgro, Montpellier, France, 28 April 2017.

17. Houssou-Goe, P. Agriculture et Changements Climatiques au Bénin: Risques Climatiques, Vulnérabilité et Stratégies D'adaptation des Populations Rurales du Département du Couffo. Master's Thesis, Universite d'Abomey-Calavi, Abomey-Calavi, Benin, 19 Decembre 2008.

18. Gnanglè, P.C.; Yabi, J.; Glèlè, K.R.; Sokpon, N. Changements climatiques: Perceptions et stratégies d'adaptations des paysans face à la gestion des parcs à karité au Centre-Bénin. SIFEComm 2005. Available online: http:/ / www.sifee.org/ressources/actes-des-colloques/actes-du-colloque-international-de-niamey (accessed on 19 January 2018).

19. INSAE (Institut National de la Statistique et de l'Analyse Economique). Cahier des Villages et Quartiers de Ville Département du Zou; INSAE: Abomey-Calavi, Benin, 2004.

20. Muzamhindo, N.; Mtabheni, S.; Jiri, O.; Hanyani-Mlambo, B. Factors Influencing Smallholder Farmers' Adaptation to Climate Change and Variability in Chiredzi District of Zimbabwe. J. Econ. Sustain. Dev. 2015, $6,1-9$.

21. Fosu-Mensah, B.Y.; Vlek, P.L.G.; Manschadi, A.M. Farmers' Perception and Adaptation to Climate Change; A Case Study of Sekyedumase District in Ghana. In Proceedings of the World Food System-A Contribution from Europe Farmers', Tropentag, Zurich, Switzerland, 14-16 September 2010.

22. Tazeze, A.; Haji, J.; Ketema, M. Climate Change Adaptation Strategies of Smallholder Farmers: The Case of Babilie District, East Harerghe Zone of Oromia Regional State of Ethiopia. J. Econ. Sustain. Dev. 2012, 3, 1-13.

23. Sani, S. Climate Change Adaptation Strategies of Smallholder Farmers: The Case of Assosa District of Benishangul Gumuz Regional State, Western Ethiopia; Haramaya University: Haramaya, Ethiopia, 2014.

24. Ouédraogo, M.; Dembélé, Y.; Somé, L. Perceptions et stratégies d'adaptation aux changements des précipitations: Cas des paysans du Burkina Faso. Sci. Chang. Planét. 2010, 21, 87-96.

25. Agossou, D.; Vissoh, V.P.; Agbossou, K.E. Adaptation aux changements climatiques: Perceptions, savoirs locaux et stratégies d'adaptation des producteurs des communes de Glazoué et de Savalou au centre du Bénin. Afr. Crop Sci. J. 2012, 20, 565-588. 
26. Oyekale, A.S.; Oladele, O.I. Determinants of climate change adaptation among cocoa farmers in Southwest Nigeria. J. Sci. Technol. 2012, 2, 154-168.

27. Cochet, H.; Ducourtieux, O.; Garambois, N. Systèmes agraires et Changement climatique: Les chemins de l'adaptation; Working Paper; AgroParisTech: Paris, France, 2017.

28. Sutcliffe, C.; Dougill, A.J.; Quinn, C.H. Evidence and perceptions of rainfall change in Malawi: Do maize cultivar choices enhance climate change adaptation in sub-Saharan Africa? Reg. Environ. Chang. 2016, 16, 1215-1224. [CrossRef]

29. Sani, S.; Chalchisa, T. Farmers' Perception, Impact and Adaptation Strategies to Climate Change among Smallholder Farmers in Sub-Saharan Africa: A Systematic Review. J. Ressour. Dev. Manag. 2016, 26, 1-8.

30. Kumari, K.A.; Kumar, K.N.R.; Narasimba Rao, C.H. Adverse Effects of Chemical Fertilizers and Pesticides on Human Health and Environment. Available online: https://www.jchps.com/specialissues/Special\% 20issue3/34\%20jchps\%20si3\%20addn\%20K.Anitha\%20Kumari\%20150-151.pdf (accessed on 19 January 2018).

31. Lin, B.B. Resilience in Agriculture through Crop Diversification: Adaptive Management for Environmental Change. BioScience 2011, 61, 183-193. [CrossRef]

32. Makate, C.; Wang, R.; Makate, M.; Mango, N. Crop diversification and livelihoods of smallholder farmers in Zimbabwe: Adaptive management for environmental change. SpringerPlus 2016, 5, 2-18. [CrossRef] [PubMed]

33. Ayenan, A.M.T.; Ofori, K.; Ahoton, L.E.; Danquah, A. Pigeonpea [(Cajanus cajan (L.) Millsp.)] production system, farmers' preferred traits and implications for variety development and introduction in Benin. Agric. Food Secur. 2017, 1-11. [CrossRef]

34. Mofya-mukuka, R.; Kuhlgatz, C.H. Nutritional Effects of Agricultural Diversification and Commercialization in Children in Zambia. In Proceedings of the AAEA Annual Meeting, Minneapolis, MN, USA, 27-29 July 2014.

35. Chen, S.E.; Salas, P.C. The Effect of Agricultural Diversification and Commercialization on the Anthropometric Outcomes of Children: Evidence from Tanzania. Available online: https://ideas.repec.org/ p/ags/aaea15/205050.html (accessed on 19 January).

36. Valdivia, C.; Hodge, S.S.; Raedeke, A. Rural Livelihoods and Agroforestry Practices in the Missouri Flood Plains. In Proceedings of the 17th Symposium of the International Farming Systems Association, Lake Buena Vista, FL, USA, 17-20 November 2002.

37. Oelbermann, M.; Smith, C.E. Climate Change Adaptation using Agroforestry Practices: A Case Study from Costa Rica. In Global Warming Impacts—Case Studies on the Economy, Human Health, and on Urban and Natural Environments; Casalegno, S., Ed.; InTech: London, UK, 2011; pp. 125-138.

38. Bugayong, L.A. Socioeconomic and Environmental Benefits of Agroforestry Practices in a Community-based Forest Management Site in the Philippines. In Proceedings of the International Conference on Rural Livelihoods Forests and Biodiversity, Bonn, Germany, 19-23 May 2003.

39. Zoysa, M.D.; Inoue, M. Climate Change Impacts, Agroforestry Adaptation and Policy Environment in Sri Lanka. J. For. 2014, 4, 439-456.

40. Torquebiau, E. Agroforestry and Climate Change; Working Paper; CIRAD: Montpellier, France, 2013.

41. Murthy, I.K.; Dutta, S.; Varghese, V.; Kumar, P. Impact of Agroforestry Systems on Ecological. Glob. J. Sci. Front. Res. 2016, 16, 15-28.

42. Juana, J.S.; Kahaka, Z.; Okurut, F.N. Farmers' Perceptions and Adaptations to Climate Change in Sub-Sahara Africa: A Synthesis of Empirical Studies and Implications for Public Policy in African Agriculture. J. Agric Sci. 2013, 5, 121-135. [CrossRef]

43. IPES-Food. Unravelling the Food-Health Nexus: Addressing Practices, Political Economy, and Power Relations to Build Healthier Food Systems; IPES-Food: Rom, Italy, 2017.

44. Food and Agriculture Organization. Climate-Smart Agriculture; FAO: Rome, Italy, 2013.

45. Food and Agriculture Organization. "Climate-Smart" Agriculture: Policies, Practices and Financing for Food Security, Adaptation and Mitigation; FAO: Rome, Italy, 2010.

(C) 2018 by the authors. Licensee MDPI, Basel, Switzerland. This article is an open access article distributed under the terms and conditions of the Creative Commons Attribution (CC BY) license (http:/ / creativecommons.org/licenses/by/4.0/). 